\title{
Optimizing Pulpwood Inventories At Roadsides, Millyards And Concentration Yards: A Case Study
}

\author{
by
}

\author{
T. A. Erdle, P. A. Arp, and C. H. Meng1
}

\begin{abstract}
A case study is presented to illustrate how pulpwood inventory profiles and inventory costs at the mill, at the roadside, and at a concentration yard can be analysed and optimized by way of computer simulation. A model, pertinent to the operational environment of the forest products company examined, was developed to account for various inventory holding costs and shortage costs, and allowed for a realistic week-by-week simulation of the Company's wood procurement and wood consumption activities.
\end{abstract}

\section{Résumé}

A partir d'une étude de cas, on illustre la simulation possible par ordinateur pour analyser et optimiser les états et les coûts des inventaires de bois à pâte au moulin, en bordure de route et dans le parc à bois. Un modèle pertinent au secteur opérationnel de l'industrie forestière fut développé pour calculer les coûts des diverses quantités de bois gardées en inventaire et les coûts des pénuries; il fut alors appliqué à la simulation d'un programme réaliste d'achat et de consommation hebdomadaire de bois.

\section{Introduction}

The enormous investments required for building, maintaining, and operating a modern pulpmill make it almost mandatory that the mill should always work at or near productive capacity and should never run out of wood. Adequate wood procurement, however, is no mean feat in view of various uncertainty factors afflicting the daily, weekly, monthly, seasonal, and annual rates at which the available pulpwood on the stump can be logged, transported, and converted for consumptive use. To buffer against possible wood shortages, especially during spring-thaw, and to allow the logging, transportation, and conversion operations (Fig. 1) to be carried out as independent of one another as possible, it is desirable to pile up wood inventories at the roadsides, at the millyard, and - if economical - at strategically located concentration points. The need for such wood piles is therefore obvious, but their optimal size and distributions are not.

The literature contains several papers on how to determine optimal inventory profiles throughout the year, with Hewson (1960), Beckett (1966), and Holemo (1971) taking the lead in conceptualizing the problem. Sellers (1971) and Tyre and Screpetis (1978) also wrote on this subject, and were mainly concerned with pulpwood inventory monitoring.

1T. A. Erdle, Research Assistant, Dept. of Forest Engineering, P. A. Arp, Assist. Prof. Dept. of Forest Resources, C. H. Meng, Assoc. Prof., Dept. of Forest Engineering, University of New Brunswick, Fredericton, NB, Canada.
The systems analysis approach was taken up by Newnham $(1973,1975)$ who developed LOGPLAN, which appears to be a complete pulpwood inventory model useful for planning inventory process controls and logging operations by way of computer calculations. Galbraith (1977), using computer simulation, focussed attention on a realistic cost assessment of pulpwood inventory problems at the millyard.

In this paper we wish to illustrate how cost-effective inventory levels at the roadsides, millyards, and readily accessible concentration yards can be determined, using pulpwood inventory data (Erdle, 1979) derived from the 1978 pulpwood inventory of an Eastern Canadian forest products company.

As will be seen, much of the pulpwood inventory problem of the Company is seasonal due to the extent of trafficability of logging roads and the duration of imposed weight restrictions on primary and secondary public highways during spring break-up when the road supporting soils become wet and soft.

\section{Background}

\section{The Company}

The Company owns a pulpwood conversion plant which is centrally located between its two adjacent wood producing land bases totalling $1.52 \times 10^{6}$ ha of which $36 \%$ represent leased Crown Lands while $64 \%$ belong to private ownership. The Company has about 2000 employees and maintains two product lines: sulphite pulp and newsprint, each manufactured at an average annual rate of 160000 tonnes and 145000 tonnes, respectively. Capacity mill requirements approximate $1200000 \mathrm{~m}^{3}$ of wood per annum. The Company, at the point of enquiry, had been unable to carry out a detailed study of its wood inventory situation and was interested in the results of such an analysis.

\section{Logging Operations}

Contract loggers are employed by the Company to harvest wood on freehold and on leased Crown Lands and, in some instances, are hired to carry out harvesting operations for private woodlot owners. These contractors perform the majority $(59 \%)$ of all harvesting activities, with the balance done by private woodlot owners on their own holdings $(26 \%)$, and Company loggers on freehold and Crown Lands (15\%).

The forests from which the Company draws its wood are characterized by small diameter trees (Abies balsamea [L.] Mill., and Picea spp.) of relatively small volume. This has led to logging operations employing either manual felling with off-road forwarding or fully mechanized systems (Koehring Shortwood Harvester, or feller buncher/processor combinations). Each type of logging delivers shortwood to the roadside. In cases where felling and off-road transport are performed by different complements of men and machines, inventories may also accrue at the stump area. In this study, such inventories (Fig. 1) are considered part of the roadside inventory. 


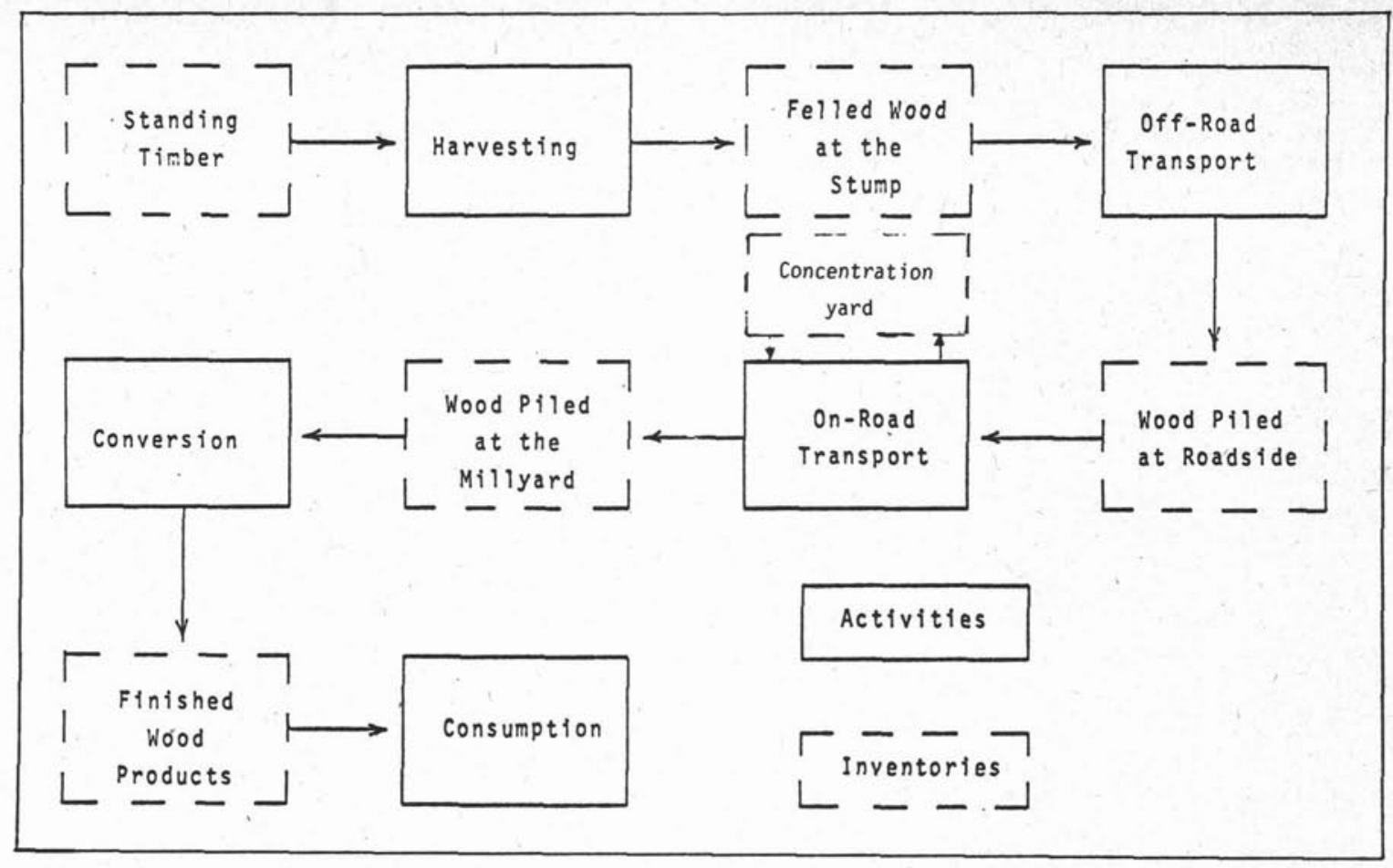

Fig. 1 Pulpwood inventories and the chain of wood procurement activities required for the continuous running of a typical pulpmill.

\section{Millyard Operations}

The wood delivered at the millyard is scaled by weight and is unloaded and piled (by Pettibone Cary-Lifts) onto the "permanent" woodpile and from there onto the life-deck which could receive wood at a maximal rate of 22603 $\mathrm{m}^{3} /$ week.

\section{On-road Transportation}

The on-road transportation from the roadside to the millyard is done by private contractors. The trucking fleet consists of 3310 -wheelers and 93 semi-trailers with an average load size per truck of $16 \mathrm{~m}^{3}$ and $28 \mathrm{~m}^{3}$, respectively. To capitalize on maximum hauling efficiencies, 10-wheelers are scheduled for hauling runs of less than $64 \mathrm{~km}$; semitrailer vehicles generally operate over longer hauling distances.

The company's potential capacity for hauling pulpwood on logging roads and highways is at least twice as large as the life-deck capacity of the mill at all times. The actual rate of pulpwood volume transported, however, is predominantly dependent on weather conditions, especially during the spring break-up season.

\section{Analysis}

\section{Rate of Pulpwood Consumption}

Wood procurement and conversion activities (Fig. 1) ultimately depend on the sales volume (and price) of the end product. Ideally, therefore, the analysis of the Company's wood inventory system should commence with an economic sales forecast to predict wood consumption levels for the future (Beckett et al., 1966). Since sales forecasting, however, is beyond the scope of this paper, past mill average weekly consumption volumes and their standard deviations (Table 1) are used as the basis for analysis. The weekly data basis suggested by Hewson (1960) and Galbraith (1977) are chosen because a daily basis greatly increases computation time, while a monthly basis is deemed too long to yield sufficiently accurate results.

\begin{tabular}{|c|c|c|c|}
\hline $\begin{array}{l}\text { Week } \\
\text { Number }\end{array}$ & Month & $\begin{array}{c}\text { Average } \\
\text { consumption } \\
\text { ( } \mathrm{m}^{3} / \text { week) }\end{array}$ & $\begin{array}{l}\text { Standard } \\
\text { deviation } \\
\text { (m³/week) }\end{array}$ \\
\hline 16 & January & 17748 & a \\
\hline $2 \cdot 14$ & January-April & 22603 & 1860 \\
\hline $15-16^{c}$ & April & 7630 & 2100 \\
\hline $17-25$ & May-June & 22603 & 1860 \\
\hline $26^{b}$ & July & 8772 & a \\
\hline $27-35$ & July-August & 22603 & 1860 \\
\hline $36^{b}$ & September & 11832 & a \\
\hline $37-40$ & September-October & 22603 & 1860 \\
\hline $41-42^{c}$ & October & 7630 & 2100 \\
\hline $43-50$ & November-December & 22603 & 1860 \\
\hline $51^{\circ}$ & December & 13668 & a \\
\hline $52^{b}$ & December & 13668 & a \\
\hline
\end{tabular}

Total annual consumption - $1068137 \mathrm{~m}^{3}$

ansufficient Company data; assumed to be zero.

b Holiday weeks.

$\mathrm{C}_{\text {Mill maintenance weeks. }}$

\section{The Roadside Inventory}

The inventory volumes at the roadside and millyard fluctuate markedly over time and are functions of the initial inventory volumes and of the rates at which wood quantities are added to or removed from roadside storage. By knowing the volumes harvested (Table 2) and transported (Table 3 ) the changes in the roadside inventory level can be calculated for each period (week of year) of consideration. The resultant period-end inventory volumes become the initial volumes for the next time interval (week) and are then adjusted by adding the harvest/transport differences. Reiteration in this manner will yield the annual roadside inventory profile as a function of time. 
Mathematically this can be expressed as:

$R I_{n}=R I_{n-1}+\mathrm{VH}_{n}-V T_{n}$,

where $\mathrm{RI}_{\mathrm{n}}$ is the roadside inventory at the end of the $n$ 'th week $(n=1,2 \ldots), \mathrm{VH}_{n}$ is the weekly wood volume harvested and transported to roadside, and VT is the weekly wood volume transported away from the roadside.

\begin{tabular}{lcc}
\hline Table 2. Wood harvesting data (Erdle, 1979) \\
\hline Month & $\begin{array}{c}\text { Harvesting } \\
\text { rate } \\
\text { (m/week) }\end{array}$ & $\begin{array}{c}\text { Standard } \\
\text { deviation } \\
\text { ( } \text { m }^{3 / \text { week }}\end{array}$ \\
\hline January & 13874 & 1387 \\
February & 17308 & 1731 \\
March & 15118 & 1512 \\
April & 9925 & 992 \\
May & 19327 & 1933 \\
June & 26283 & 2628 \\
July & 24780 & 2478 \\
August & 27458 & 2746 \\
September & 27758 & 2776 \\
October & 26901 & 2690 \\
November & 21275 & 2128 \\
December & 15790 & 1579 \\
\hline Total annual harvest $-1068137 \mathrm{~m}^{3}$ & \\
\hline
\end{tabular}

\begin{tabular}{|c|c|c|c|}
\hline Season & Week & $\begin{array}{c}\text { Average } \\
\text { delivery rate } \\
\text { (m3/week) }\end{array}$ & $\begin{array}{l}\text { Standard } \\
\text { deviation } \\
\left(\mathrm{m}^{3} / \text { week }\right)\end{array}$ \\
\hline $\begin{array}{l}\text { Holiday } \\
1 \\
2 \\
3 \text { a } \\
4 \\
\text { Holiday } \\
4 \\
\text { Holiday } \\
4 \\
5 \\
\text { Holiday } \\
\text { Holiday }\end{array}$ & $\begin{array}{l}1 \\
2-5 \\
6-10 \\
11-17 \mathrm{~b} \\
18-25 \\
26 \\
27-35 \\
36 \\
37-43 \\
44-50 \\
51 \\
52\end{array}$ & $\begin{array}{r}14266 \\
18311 \\
21481 \\
6018 \\
26098 \\
21302 \\
26098 \\
25894 \\
26098 \\
20890 \\
9755 \\
1563\end{array}$ & $\begin{array}{c}c \\
2 \\
2425 \\
1650 \\
3025 \\
4950 \\
c \\
4950 \\
49 \\
4950 \\
32290 \\
c \\
c\end{array}$ \\
\hline
\end{tabular}

Total annual delivery $-1068137 \mathrm{~m}^{3}$

aSpring break-up season.

b Average road weight restriction period; for actual durations see Figure 3.

Insufficient Company data; assumed to be zero.

\section{The Millyard Inventory}

The wood inventory at the millyard is regulated by the volumes of wood delivered and removed from millyard storage. The calculations for the millyard inventory level are, therefore, identical to those outlined for the roadside except that the harvesting/transport differences are replaced by the transport/consumption differences. Hence

$$
M I_{n}=M I_{n-1}+V T_{n} \cdot V C_{n} \text {, }
$$

where $\mathrm{MI}_{n}$ is the millyard inventory at the end of the time period $n$, and $V_{C_{n}}$ is the corresponding wood volume consumed.

There are two other important inventory constraints to be considered:

(1) The millyard has a limited pulpwood storage capacity of $255000 \mathrm{~m}^{3}$. When this capacity is reached, the managers suspend the transport operations and retain all deliveries at the roadside, where for all practical purposes no storage. limits exist. This constraint is incorporated in the model, by setting $\mathrm{VT}_{\mathrm{n}}=0$ whenever $\mathrm{MI}_{\mathrm{n}}>255000 \mathrm{~m}^{3}$.

(2) It is possible that a negative value may be calculated for the millyard inventory level. Such a value indicates that shortages have occurred, which, to a certain extent, can be remedied by hauling more wood from the roadside. To incorporate this activity into the model below, a negative millyard inventory value is set to zero, while the roadside inventory is reduced by an amount equal to that of the millyard shortage.

Wood shortages at the roadside can be eliminated by accelerating the harvesting activities or by purchasing wood from other sources. The model handles this contingency by setting negative roadside inventory values to zero and by maintaining delivery of needed wood to the mill, while any additional costs incurred by so doing will be accounted for.

\section{Pulpwood Inventory Cost Assessment}

There are two types of inventory costs to be considered: holding costs (defined below), and shortage costs relevant when millyard and/or roadside inventories have been exhausted.

\section{(a) Holding Costs}

Unit holding costs consist of (i) interest rates foregone by freezing capital, (ii) fibre deterioration losses, and (iii) insurance premiums of wood stores against fire and other losses (Galbraith, 1977). Realistic values for these costs as percent of the total unit value of the wood stored - are given in Table 4.

\begin{tabular}{lcl}
\hline \multicolumn{3}{l}{ Table 4. Inventory unit holding costs } \\
\begin{tabular}{lcl}
\hline Interest rate & Fibre deterioration rate & Insurance rate \\
\hline $12.00(\% / \mathrm{yr})$ & $0.86(\% / \mathrm{mo})^{\mathrm{a}}$ & $0.79(\% / \mathrm{yr})$ \\
$0.23(\% / \mathrm{wk})$ & $0.20(\% / \mathrm{wk})$ & $0.0152(\% / \mathrm{wk})$ \\
\hline
\end{tabular}
\end{tabular}

aEstimated by Galbraith (1977).

\section{(b) Shortage Costs}

The Company management provided approximate premium rates which would be incurred if transportation and harvesting activities were to be accelerated to remedy possible wood shortages at the mill and at the roadside. From these premium rates it was possible to estimate that the delivery of extra wood to the mill (above the mean seasonal value) would cost (conservatively) $\$ 5.00$ per $\mathrm{m}^{3}$, while the acceleration of harvesting and off-road transportation of extra shortwood to the roadside would cost (conservatively) $\$ 10.00$ per $\mathrm{m}^{3}$.

These values, however, cannot be applied to any volume of extra wood required, since there are limits to which the increased wood producing activities can provide the needed wood at these unit costs. Wood requirements beyond these limits would necessarily be accompanied by even higher unit costs, and may lead to "non-recoverable" wood shortages, i.e. loss of sales, the cost of which must be reflected in the overall pulpwood inventory cost assessment.

To accommodate any wood shortage costs including those from loss of sales it was decided that:

(1) any weekly mill wood shortage up to $2000 \mathrm{~m}^{3}$ could be filled at a cost of $\$ 5.00$ per $\mathrm{m}^{3}$, while shortages above this level would be charged at a maximal cost of $\$ 90.00$ per $\mathrm{m}^{3}$;

(2) any weekly roadside wood shortages less than $3000 \mathrm{~m}^{3}$ could be remedied at a cost of $\$ 10.00$ per $\mathrm{m}^{3}$, with shortages above that limit costing $\$ 90.00$ per $\mathrm{m}^{3}$ (maximum).

\section{(c) Other Costs}

The taxes incurred on storage site land were difficult to isolate, but were estimated to represent a minor portion of the total property tax levied on the Company and where thus considered negligible. The handling expense associated with transferring the delivered wood from the millyard store to the live- deck of the pulp mill was estimated to be $\$ 0.80$ per $\mathrm{m}^{3}$, but this expense was omitted, because the total annual millyard wood handling cost was assumed to be fixed 
as it would depend on the total annual rate of pulpwood consumption. This cost, therefore, is part of the fixed operating cost of the mill. Costs due to prospective sales losses incurred by a temporary but non-correctable pulpwood shortage at the mill are difficult to estimate, and are not considered.

\section{(d) The Total Cost Equation}

Each of the various costs considered must be applied to the monetary value and/or to the volume of the pulpwood inventory at any time and place. To do so it was decided to fix the price for shortwood delivered and piled at the roadside to a value of $R C=\$ 11.27$ per $\mathrm{m}^{3}$, whereas at the millyard the value of the received and piled pulpwood was set to $\mathrm{MC}=\$ 17.23$ per $\mathrm{m}^{3}$.

Applying the unit holding costs against the pulpwood unit values, and considering any possible shortage costs one obtains the following equation for the total weekly pulpwood inventory cost $T_{n}$ :

$$
\mathrm{T}_{\mathrm{n}}=\mathrm{CRI}_{\mathrm{n}}+\mathrm{CMI}_{\mathrm{n}} \text {, }
$$

where

$$
\begin{aligned}
& =C R I_{n}=\left(R I_{n} \bullet R C\right)(i+d+p), \text { when } R I_{n} \geqslant 0, \\
& =\$ 10.00 R I_{n}, \quad \text { when }-3000 \leqslant R I_{n} \leqslant 0, \\
& =\$ 90.00\left(R I_{n}-3000\right)+\$ 30000.00, \text { when } R I_{n}<-3000,
\end{aligned}
$$
and

$\mathrm{CMI}_{n}=\left(\mathrm{MI}_{\mathrm{n}} \bullet \mathrm{MC}\right)(\mathrm{i}+\mathrm{d}+\mathrm{p})$, when $\mathrm{MI}_{\mathrm{n}} \geqslant 0$,

$$
\begin{aligned}
& =\$ 5.00 \mathrm{MI}_{\mathrm{n}}, \quad \text { when-2 } 000 \leqslant \mathrm{MI}_{\mathrm{n}} \leqslant 0, \\
& =\$ 90.00\left(\mathrm{MI}_{\mathrm{n}}-2000\right)+\$ 10000.00, \text { when } \mathrm{MI}_{\mathrm{n}}<-2000,
\end{aligned}
$$

and $i$ is the interest rate per week, $d$ is the cost of fibre deterioration per week, and $p$ is the insurance rate per week.
The annual total inventory cost T will then be given by

$$
T=\sum_{n=1}^{52} T_{n} \bullet
$$

The year-after-year average total annual inventory cost $\bar{T}$ referred to below is the average of $T$ obtained for each year of the various 100 -year inventory simulation runs.

\section{The Model}

An iterative FORTRAN IV simulation model ${ }^{2}$ based on Equations [1], [2] and [3] was developed to calculate the Company's average roadside and millyard inventory profiles and costs throughout the year. The flow chart of this model is given in Fig. 2. For the purpose of validation the model was run in its simplest form by using the average rates of harvesting, transportation, and consumption. To simulate the real-life situation, however, the uncertainty associated with these activities (Tables 1, 2, 3) had to be taken into account. This was done by way of Monte Carlo calculations, using computer generated random numbers, the frequency distributions of which were adjusted to match those of $\mathrm{VH}_{n}$, $V_{C_{n}}$, and $V T_{n}$ precisely. In this way actual and realistic values for $R I_{n}$ and $M I_{n}$ were obtained for each week in each 100 -year simulation. From each such simulation the average long term inventory profiles and costs could then be determined, and the probabilities and extent of possible wood shortages at the mill and at roadside could be assessed at the same time.

In the model we assume that $\mathrm{VH}_{n}, \mathrm{VC}_{n}$, and $\mathrm{VT}_{n}$ are not correlated with one another, to enable the Company to carry out its logging, transportation, and conversion operations as independently of one another as possible to reduce

\footnotetext{
${ }^{2} \mathrm{~A}$ copy of the computer program listings for the model can be obtained from C.H. Meng.
}

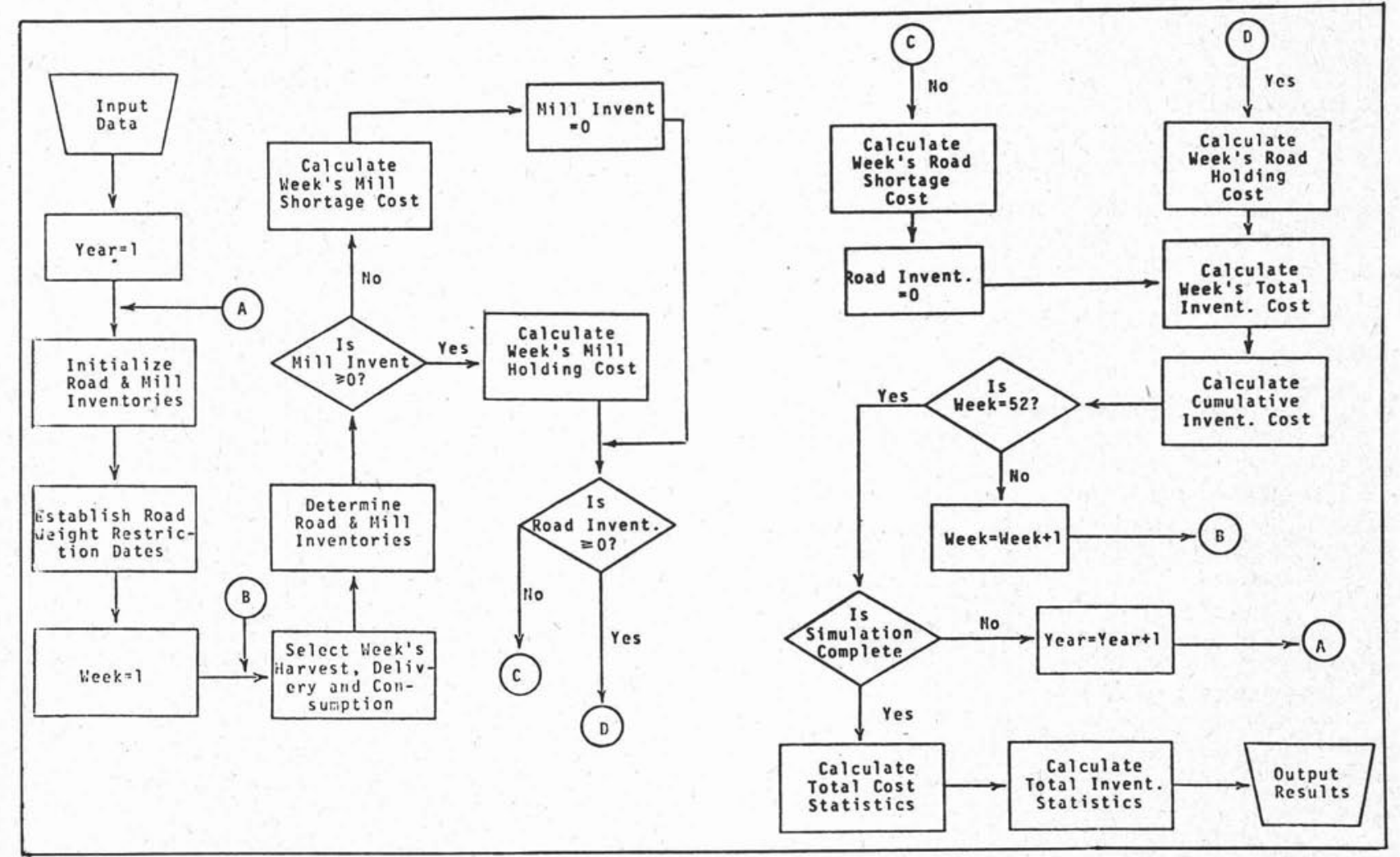

Fig. 2 Flowchart of the pulpwood inventory cost assessment model described in the text. 
the frequency of costly, inefficient, and generally disruptive inventory control actions. Undoubtedly, this requirement will increase the size of the optimal pulpwood inventory levels, but the added size of such levels should provide a good insurance against frequently recurring inventory problems, predominantly in the form of shortages.

We wish to point out that these calculations included the simulation of the variable and uncertain onset and duration of the crucial spring break-up season, again using random numbers the frequency distributions of which matched those of the road weight restriction commencement and duration dates for the last 20 years (Fig. 3).
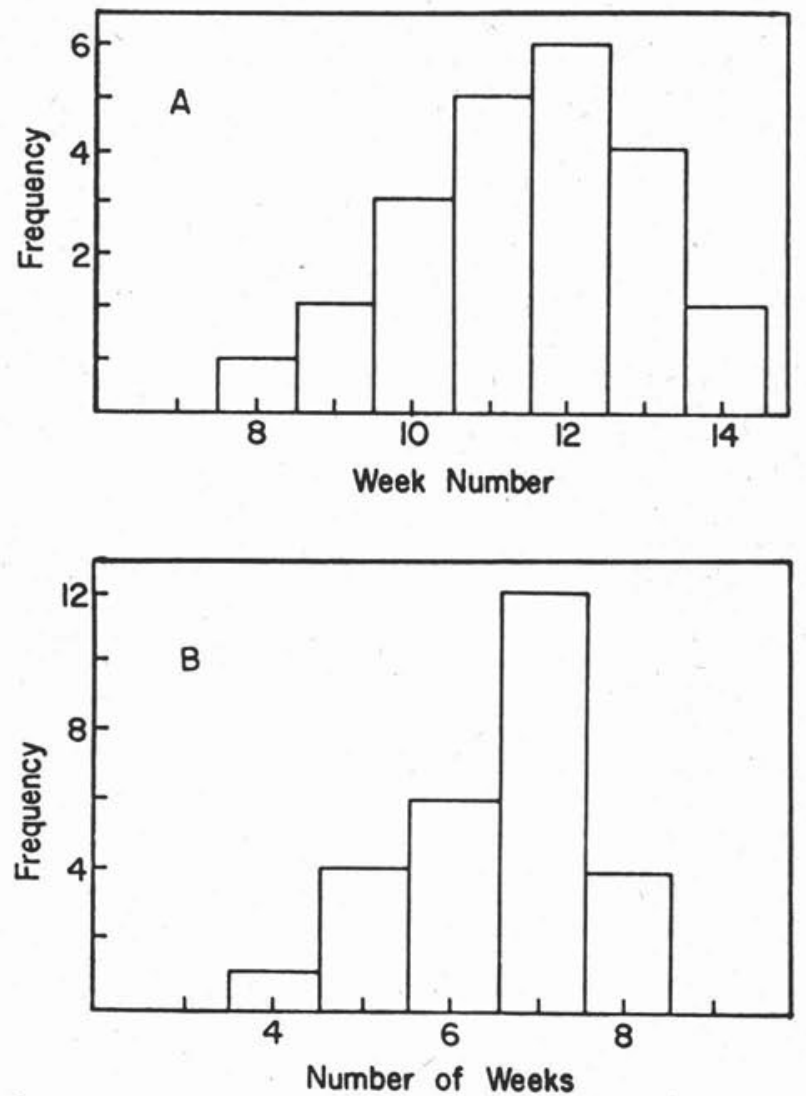

Fig. 3 Onset (upper) and duration (lower) histograms of the spring break-up season as observed during the last 25 years by the Company's pulpmill management.

\section{Results}

\section{The Least Cost Inventory Base Volumes}

Since the harvest, delivery and consumption activities each follow an annually recurring pattern it is reasonable to expect that the optimum inventory volumes to be established for any period (week) of the year will establish the optimum inventory profile for each and every year (Galbraith, 1977).

The beginning period of the simulated inventory year was the week associated with July 1st (termed the base week). The millyard and roadside inventory volumes present at this time of year are defined to be the base volumes.

Any week of the year could have been used for the base week, but the first week in July was selected because it falls shortly after the onset of favorable weather conditions when Company operations would be least restricted by weather, in case inventory adjustment at the roadside and at the millyard would have to be made by accelerated harvesting and/or delivery activities.
The optimal inventory profiles were determined by setting the roadside and millyard base volumes to any particular levels under study. For instance, the first simulation trial was made using the then current average inventory base volumes of the Company which at the mill and at the roadside were $\mathrm{MI}_{0}=124440 \mathrm{~m}^{3}$ and $\mathrm{RI}_{0}=120360 \mathrm{~m}^{3}$, respectively. Using these as input data and simulating the inventory profile for 100 years with the model above yielded an average total annual inventory cost of $\bar{T}=\$ 956000$. No wood shortages arose at roadside, while insufficient millyard inventories occurred at a rate of one week in every 50 years, always starting near the end of the spring break-up season.

Since there are two pulpwood inventories (millyard and roadside), it was necessary to hold one base volume constant while testing the effects of varying the other. Different millyard base volumes were tested first, with the base roadside volume maintained at $\mathrm{RI}_{0}=120360 \mathrm{~m}^{3}$. Starting with a millyard inventory of $\mathrm{MI}_{0}=20000 \mathrm{~m}^{3}$, eight 100 -year simulations were made, incrementing the base volume by 20000 $\mathrm{m}^{3}$ for each consecutive run. The results are presented in Figure 4, and in Figure 5 (upper curve).

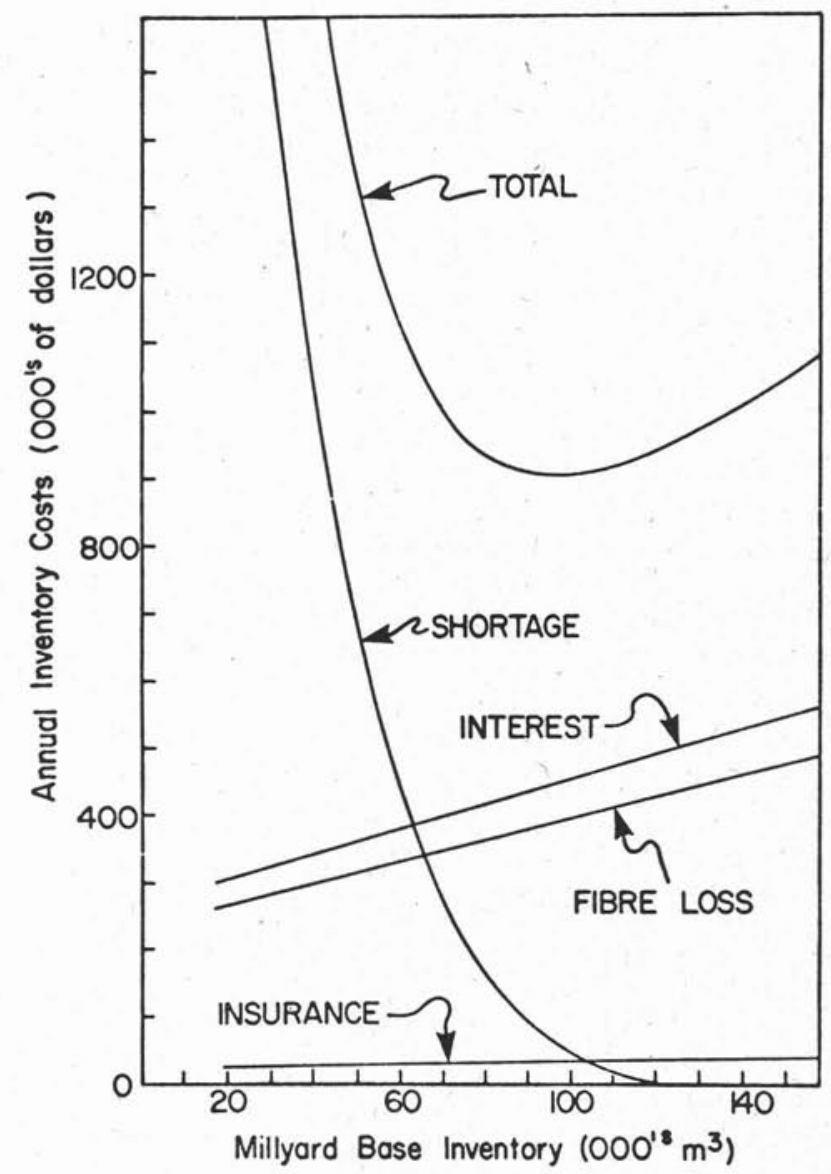

Fig. 4 Average total annual inventory costs versus the base (July 1st) millyard inventory volume when the base roadside inventory volume is set at $120360 \mathrm{~m}^{3}$. Also shown are the inventory shortage, interest, fibre loss, and insurance costs, as indicated.

The cost curves in Figure 4 reveal how total inventory cost is affected by the magnitude of storage costs and holding costs. The steeply sloping portion of the total cost curve, corresponding to low inventory base volumes, stems from the frequent occurrence of millyard wood shortages and from the high unit cost $\left(\$ 90 / \mathrm{m}^{3}\right)$ assigned to such shortages. The right-hand-segment of the curve slopes less 
sharply as shortages occur less frequently. In fact, for base volumes greater than $\mathrm{MI}_{0}=125000 \mathrm{~m}^{3}$, no millyard shortages will occur, and the shortage costs drop to zero. Beyond this point, the total cost curve takes on a constant slope equal to the sum of the interest, fibre deterioration and insurance costs.

Figure 5 reveals that the average total annual inventory costs are minimized when the millyard base volume lies between 80000 and $120000 \mathrm{~m}^{3}$. To identify the least cost volume more accurately, a second simulation trial was made, setting the millyard base volume to $80000 \mathrm{~m}^{3}$, and making six successive tests at $5000 \mathrm{~m}^{3}$. increments.

The results of these simulations are displayed in Table 5, and indicate that carrying a millyard inventory of $\mathrm{MI}_{0}=95000 \mathrm{~m}^{3}$ should yield the lowest yearly inventory cost of $\bar{T}=\$ 905000$ according to the present Company wood procurement patterns. To arrive at the overall leastcost base volumes, a second simulation series was run in which the millyard base volume was held at the least cost level of $\mathrm{MI}_{0}=95000 \mathrm{~m}^{3}$, while the roadside base volume was varied. Altogether nine simulation trials were made using roadside base volumes ranging from $\mathrm{RI}_{0}=40000 \mathrm{~m}^{3}$ to $120000 \mathrm{~m}^{3}$, by $10000 \mathrm{~m}^{3}$ increments.

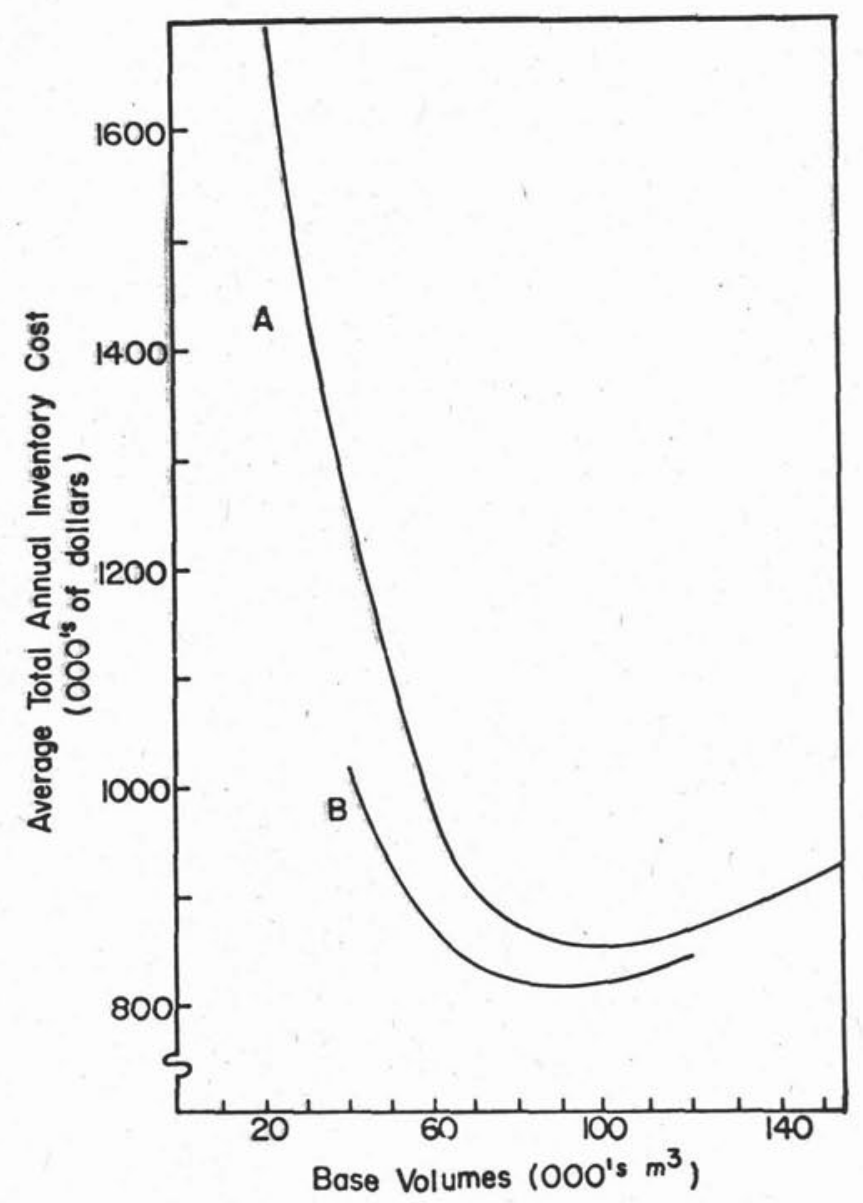

Fig. 5 Average total annual inventory costs versus base (July 1st) inventory volumes when the base roadside inventory volume is set at $120360 \mathrm{~m}^{3}$ (upper curve, A) and when the millyard inventory volume is set at $95000 \mathrm{~m}^{3}$ (lower curve, B).

The results of these simulation runs are presented by the lower cost curve of Figure 5, which reveals that carrying a July 1st roadside inventory of $\mathrm{RI}_{0} \equiv 90000 \mathrm{~m}^{3}$ yields the lowest average total annual cost of $=\$ 843000$.
Table 5. Total annual inventory costs as affected by millyard base inventory volumes. The roadside base inventory is $120360 \mathrm{~m}^{3}$.

\begin{tabular}{lccccc}
\hline $\begin{array}{l}\text { Millyard base inventory } \\
\left(00 \text { 's }^{3} \text { @ July 1st) }\right.\end{array}$ & 80 & 85 & 90 & 100 & 105 \\
$\begin{array}{l}\text { Average total inventory } \\
\text { Cost (000's dollars/year) }\end{array}$ & 952 & 928 & 909 & 908 & 912 \\
\hline
\end{tabular}

Consequently it would appear that the Company can reduce its average total annual inventory cost by approximately $\$ 113000$ provided that the inventory base (= July 1) volumes are adjusted from their present levels to 95000 and $90000 \mathrm{~m}^{3}$ at the mill and at the roadsides, respectively. A further reduction in $\tilde{\mathrm{T}}$, perhaps, can be obtained by varying the base levels at the roadsides and the millyard simultaneously.

\section{Sensitivity Analysis}

The placement of a dollar value on the potential savings and specification of the least-cost inventory volumes assumes that all the unit cost factors of the model are valid. This, however, may rarely be the case. Galbraith (1977) contended that the least-cost volume was not affected by changes in holding costs. Thus, having determined the average inventory profile through simulation, it is a minor task to calculate the components of the mean annual holding costs when unit costs for insurance, fibre loss and interest need adjustment.

The effects of unit shortage cost changes on the total costs, however, could only be ascertained by further simulation runs. These runs were made by changing the unit shortage costs from $\$ 90$ to $\$ 60$ and $\$ 30$ per $\mathrm{m}^{3}$ and by varying the millyard base volume while the roadside base volume was held constant at $90000 \mathrm{~m}^{3}$. The results are shown in Figure 6 and in Table 6 . Notice that both the total annual inventory cost and the least-cost millyard base volumes are strongly affected by changing the unit shortage costs. Hence, it is important to specify accurate unit shortage costs, a task which may be difficult since sales losses and possible loss of consumer good-will are involved.

Table 6. Least-cost millyard base volumes and total annual inventory costs associated with varying unit shortage costs. The loose roadside inventory is $90000 \mathrm{~m}^{3}$.

\begin{tabular}{ccc}
\hline $\begin{array}{c}\text { Unit shortage cost } \\
\left(\mathbf{\$} / \mathbf{m}^{\mathbf{3}}\right)\end{array}$ & $\begin{array}{c}\text { Least cost millyard } \\
\left.\text { base inventory } \mathbf{( m}^{\mathbf{3}}\right)\end{array}$ & $\begin{array}{c}\text { Total annual } \\
\text { inventory cost } \mathbf{( \$ )}\end{array}$ \\
\hline 30.00 & 75000 & 782000 \\
60.00 & 85000 & 819000 \\
90.00 & 95000 & 843000 \\
\hline
\end{tabular}

\section{The Concentration Yard: Economic Feasibility Considered}

A number of minor modifications and additions to the model above were made to evaluate the cost-effectiveness of an all-season accessible concentration yard centrally located on one of the two pulpwood land bases of the Company. The distance between the concentration yard and the mill was approximately $110 \mathrm{~km}$. The average cost of wood delivered to the concentration yard was determined to be $\$ 14.87$ per $\mathrm{m}^{3}$. The concentration yard holding costs for interest, insurance, and fibre loss were assessed against this value which compares favourably with the value of $\$ 17.23$ per $\mathrm{m}^{3}$ for the wood when piled at the mill. 


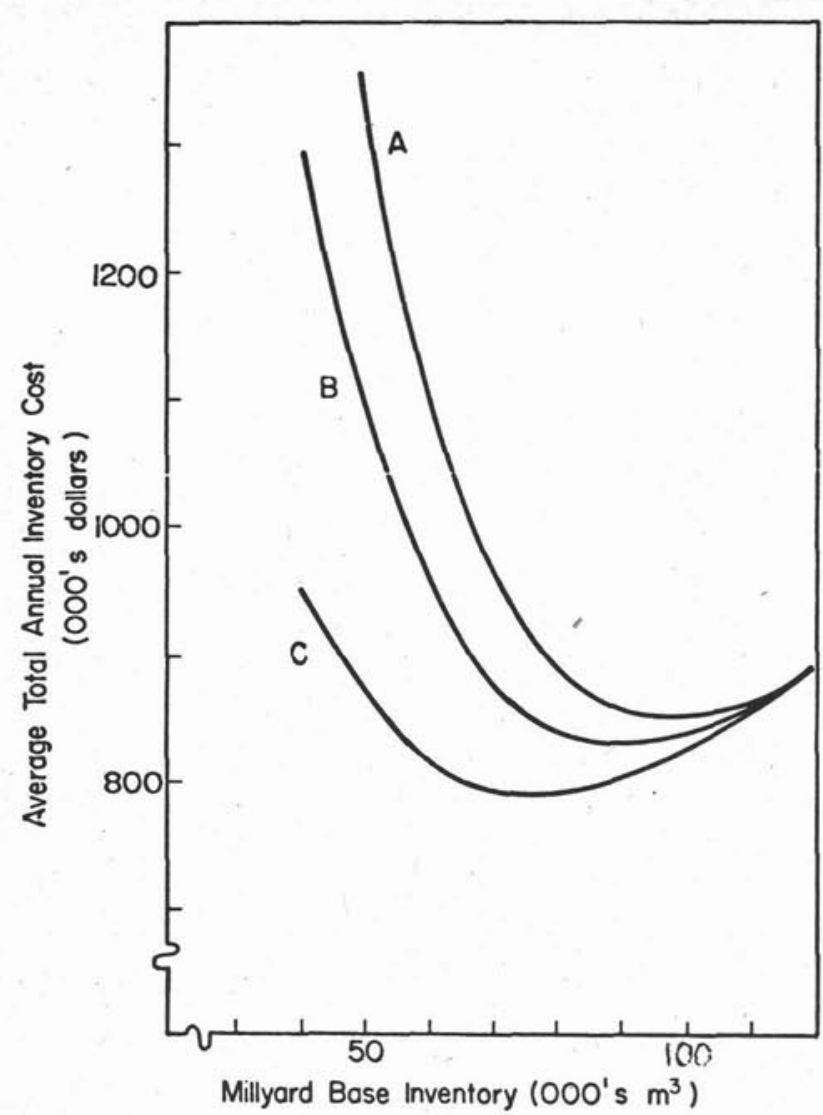

Fig. 6 Average total annual inventory costs when the base (July 1st) inventory volume at the roadside is set at $90000 \mathrm{~m}^{3}$, and the unit shortage costs (Equation [3] are varied from $\$ 90$ (upper curve, A) to $\$ 60$ (middle curve, B) and to $\$ 30$ (lower curve, C).

Company managers felt that wood transported to the mill during the spring break-up season when the mill yard stores would be at their lowest could be delivered from the concentration yard directly to the live-deck. The extra handling cost arising from the concentration yard $\left(\$ 1.18 \mathrm{~m}^{3}\right)$ would then be partially offset by eliminating the intra-millyard transfer of wood costing $\$ 0.80$ per $\mathrm{m}^{3}$. Therefore, the net handling cost of directing the flow of wood from the concentration yard to the live-deck should be $\$ 0.38$ per $\mathrm{m}^{3}$.

The average single-trip cost between the roadsides and the mill was approximately $\$ 4.77$ per $\mathrm{m}^{3}$, while the doubleleg hauling cost (roadside to concentration yard to mill) was about $\$ 5.92$ dollars per $\mathrm{m}^{3}$. Consequently, an extra transportation expense of $\$ 1.15$ per $\mathrm{m}^{3}$ was added to the $\$ 0.38$ handling cost yielding a total additional cost of $\$ 1.53$ for each unit of wood delivered to the mill from the concentration yard.

To answer the question: "Is the reduction in wood holding costs obtained by using a concentration yard sufficient to outweigh the extra handling and transportation expense?" a simulation trial was made using the following input data:

(1) the base volumes were set to $95000 \mathrm{~m}^{3}$ and $90000 \mathrm{~m}^{3}$ at the millyard and roadside, respectively,

(2) the cost parameters as outlined above were used, and

(3) the concentration yard was to be filled to its capacity of $51000 \mathrm{~m}^{3}$ during September and October, the "best weather" months for harvesting operations.
The results of the simulation revealed that the use of the concentration yard yielded an average total annual inventory cost of $\overline{\mathrm{T}}=\$ 907000$. This was a $\$ 64000$ increase over the annual cost incurred when the system was operated without this yard. Storing wood in the concentration yard represented an annual holding cost saving of $\$ 14000$, but this benefit was outweighed by the extra transportation and holding expenses of $\$ 78000$ per year.

Perhaps - as was suggested - substantial holding cost savings could be made by filling the concentration yard at an earlier date, thus further reducing the inventory volume at the millyard. In order to test this possibility, the model was run using July and August as fill-up period. It was found that in this manner only $\$ 5000$ could be trimmed off the annual inventory cost, yielding an average total annual inventory cost of $T=\$ 902000$.

Ignoring the advantages that might accure from a reduction in the truck fleet, it is apparent that the concentration yard will produce extra inventory costs should the Company make it operational. The maintenance of concentration yard inventories, at least in this instance, does not appear to reduce inventory costs mainly because the millyard versus concentration yard unit cost differential is not large enough. Further simulation runs would show that the costeffectiveness of the concentration yard may depend on the distance between this yard and the mill. Perhaps an optimal distance may be found for which the use of the concentration yard would become an economic feasibility. Such a possibility, however, should strongly depend on the transportation costs, which are likely to continue to increase much faster than any other inventory costs to be considered.

\section{Conclusions}

In general, the construction of a wood inventory system model is not a simple undertaking, nor is the formulation of a sound wood inventory policy. It is hoped, however, that the case study presented herein has served to elucidate the fundamental considerations required for pulpwood inventory management.

The use of a model cannot define the best inventory policy to follow, but can be helpful to analyze, interpret and predict the company's operational inventory environment and options as they may change from year to year. The value of such analytical work, however, is contingent upon the accuracy of the model and upon the flexibility, and convenience with which the model can be used.

In this study, the terms average least-cost inventory and optimal inventory profiles have been used synonymously. Optimality, within the context of a given inventory policy, however, is ultimately defined by the pulpwood shortage risk a company is willing to assume. For example, the pulpwood shortage risk at the mill drops to zero when the annual July 1 st base volumes at the mill and at the roadside are set to 120360 and $118000 \mathrm{~m}^{3}$, respectively, every year. The additional inventory cost incurred by this "non-optimal" adjustment (equivalent to $\$ 0.30$ per $\mathrm{m}^{3}$ ) is an extra cost which most pulpmill managers perhaps are willing to pay to guarantee "zero shortage" year after year.

\section{Acknowledgements}

This work received financial support from NSERC, Grant No. A8411. Helpful discussions, cooperation, and correspondence with Mr. R. Waycott and Mr. A. Thor of Nova Scotia Forest Industries, and Professor G. Lapointe of UNB are gratefully acknowledged. 


\section{References}

Beckett, W. A. and Associates. 1966. A model for pulpwood inventory Control. Res. Pap. for Woodlands Sci. Counc., CPPA. 44 pp.

Erdle, T. A. 1979. Wood Inventory Management: A case study of policy formulation. B.Sc.F. Thesis, University of New Brunswick, Fredericton, NB

Galbraith, J. E. 1977. An economic analysis of pulpwood inventory requirements. MScF thesis, University of New Brunswick, Fredericton, NB pp. 91.

Hewson, T. A. 1960. Simulation of pulpwood inventory dynamics in the operation of an integrated pulp and paper mill. Tappi, 43 (6): 518-527.

Holemo, F. J. 1971. Inventory management - The tool and need in lumber production. For. Prod. J. 21 (1): 12-16.

Newnham, R. M. 1973. Process control in forest harvesting. For. Chron. 49: 35-40.

Newnham, R. M. 1975. LOGPLAN - A model for planning logging operations. For. Man. Inst. Inf. Rep. No. FMR-X-77, pp. 59.

Sellers, A. M. 1971. How Great Lakes control wood delivery, inventory. Can. For. Ind. (6): 34-37.

Tyre, G. L. and G. D. Screpetis. 1978. System for roundwood inventory and control of veneer, saw timber, and pulpwood volumes. For. Prod. J. 28 (1): 40-41

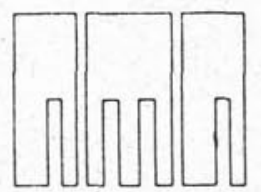

\section{Alan Moss \& Associates Ltd.}

Consultants in Forestry and Forest Industries

\section{Domestic and International}

1334 St. Paul Street

Kelowna, British Columbia V1Y 2E1

Telephone: (604) 763-4811

Cable: Sylva

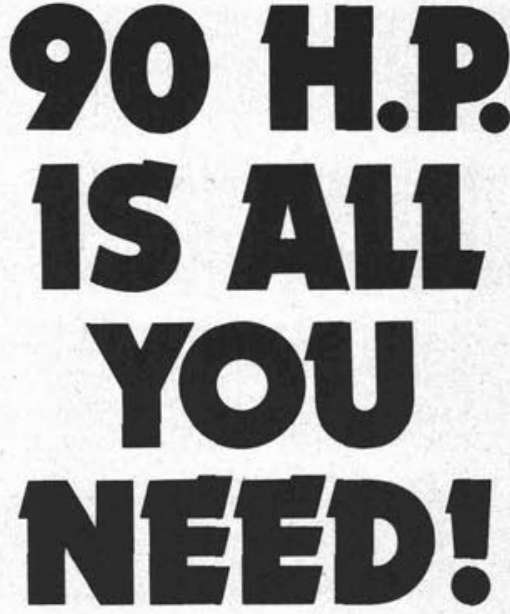

That's all you need to power the C.F.E. PATCH SCARIFIER!

Imagine being able to do your Site Preparation work with Any available skidder.

The PATCH SCARIFIER has now been Redesigned \& Built Stronger, to handle the toughest jobs!

Compact and Agile, it works well on steep ground, in rock, and through wet spots.

Also, the PATCH SCARIFIER can scarify 2 to 3 acres per hour at a cost of only $\$ 30$ per hour.

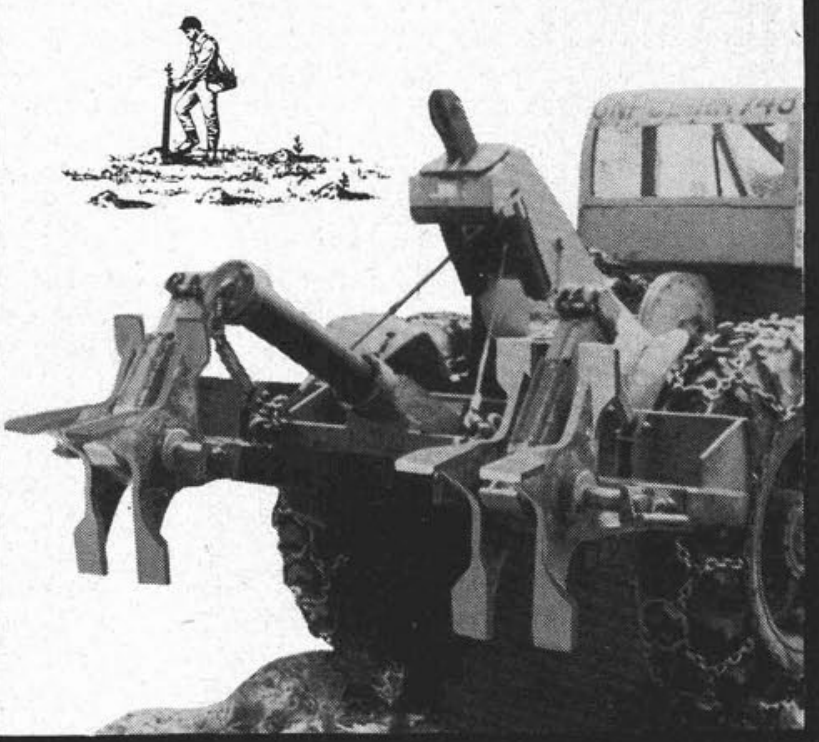

Nonadian Forestry

Equipment, Ltd."The Reforesters

567 Drew Road, Mississauga, Ontario (416) 678-1586 17212.106 Avenue, Edmonton, Alberta (403) 484-6687

320 Maple Street, Frederiction, New Brunswick (506) 474-0678 